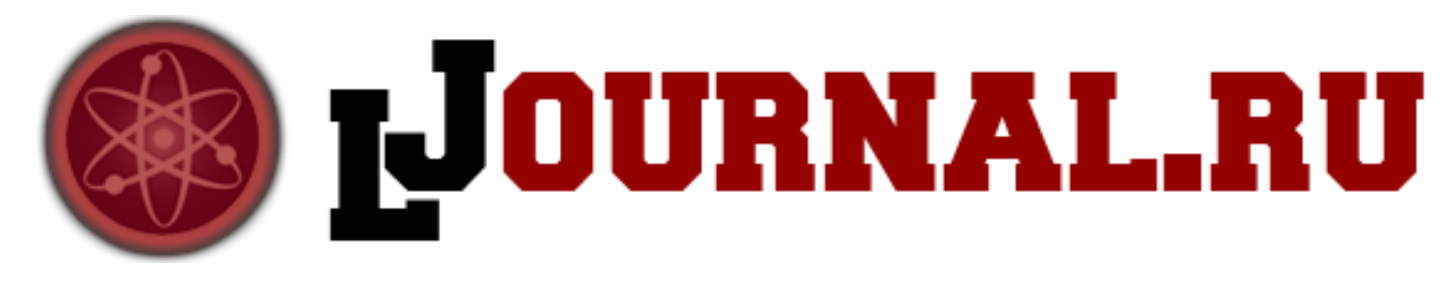

Михайлова В.А., Петрова М.В., Вагапова Г.А., Асфандиярова Э.С. Стерлитамакский филиал БашГУ Стерлитамак, Россия

doi: 10.18411/lj2016-1-11

\title{
Инвентаризация грибов-макромицетов кугарчинского района
}

Грибы образуют крупнейшее царство живой природы, которое остаётся одним из наименее изученных. Основная роль грибных организмов в биосфере участие в разложении сложных органических соединений. Это позволяет ускорить и упростить круговорот вещества и энергии.

К сожалению, уровень изученности биоты грибов-макромицетов России и отдельных регионов остаётся неудовлетворительным. В особенности это касается лесных районов, к которым относится и территория Кугарчинского района.

\section{Природные условия района исследования}

Кугарчинский район расположен в южной части Республики Башкортостан, на левобережье реки Белой. Территория района граничит на западе с Оренбургской областью и Куюргазинским районом, на севере с Мелеузовским, на востоке с Бурзянским и Зилаирским и на юге с Зианчуринским районами республики [1]. Район расположен в Предуральской степи, однако в пределах района выделяют следующие микрозоны: западную (типичный лесостепной ландшафт) и восточную (горно-лесная зона).

По характеру растительного покрова западная часть района относится к лесостепной зоне и характеризуется распространением луговых степей и островков лиственных лесов, которые занимают около $20 \%$ территории. Естественный травостой сохранился местами по крутым склонам и у опушек 
леса. Он состоит из ковылей перистого, тырсы и узколистного типчака. Разнотравье района представляют люцерна степная, клевер горный, чабрец Маршалла, шалфей степной, многочисленные полыни и лапчатки, в луговых степях - девясил, горицветы, лабазник, гвоздики и др. Территория Кугарчинского лесхоза по лесорастительному районированию отнесена к горнолесной зоне широколиственных лесов западного склона Южного Урала. Основные лесообразующие породы для данной местности: береза, дуб, липа, клен, осина; для восточной части кроме этих пород - сосна и лиственница.

Почвенный покров территории района характеризуется доминированием выщелоченного, оподзоленного и типичного чернозема. По механическому составу преобладают тяжелосуглинистые и глинистые почвы.

Для территории района характерен резко выраженный континентальный климат. Среднегодовая температура воздуха $+2,5^{\circ}$, количество осадков 336 мм в год, распределение их по годам и по периодам года крайне неравномерно, в среднем два года из пяти бывают засушливыми. Острозасушливыми были 1975 и 1998 годы. Преобладающие ветры: осенне-зимний период - южных и восточных направлений [2].

\section{Материалы и методы исследования}

Исследование микобиоты проводилось нами в Кугарчинском районе с целью изучения биоразнообразия грибов-макромицетов и выявления особенностей их распространения на данной территории в период с весны 2005 по осень 2011 года.

Нами была исследована территория Кугарчинского района, находящаяся в южной части республики Башкортостан, в частности: северная часть района посёлок Юмагузино; западная часть района - деревня Худайбердино; южная часть - сёла Максютово, Кугарчи, Ижбердино; юго-западная - Подгорное, Исимово, восточная часть - деревни Юлдыбаево, Мурадымово и юго-восточная часть - деревни Давлеткулово и Тукатово. Всего было исследовано 11 населенных пунктов, находящихся в разных частях района. 
Классификация грибов-макромицетов дана в соответствии с новыми правилами классификации макромицетов. При определении и систематизации таксонов за основу была использована система высших грибов, основанная на системе В. Юлиха и Д. Хаксворта и опубликованная Хенингом Кнудсеном в книгах «Nordic Macromycetes» $[3,4,5]$. При анализе эколого-трофической структуры базидиомицетов за основу была взята шкала трофических групп, предложенная А. Е. Коваленко [6].

Редкий компонент микобиоты определялся в соответствии с данными Красной книги Республики Башкортостан [7].

\section{Результаты исследования и их обсуждение}

Таксономический анализ макромицетов Кугарчинского района

В результате проведённого исследования был составлен систематический список макромицетов Кугарчинского района Республики Башкортостан. За 2005 - 2011 гг. изучения микобиоты был собран и определен 112 видов грибовмакромицетов.

Общий систематический список состоит из двух отделов Ascomycota и Basidiomycota, двух классов (Pezizomycetes и Hymenomycetes), 14 порядков, 27 семейств, 42 родов и 112 видов. Отдел Ascomycota представлен всего пятью видами, относящимися к трем родам, двум семействам и одному порядку. Наиболее многочисленным является отдел Basidiomycota, включающий один класс, 13 порядков, 24 семейства, 39 родов и 107 видов.

Из необычных находок на территории Кугарчинского района следует отметить редкие виды шляпочных грибов, занесённых в Красную книгу Республики Башкортостан. В единичном экземпляре найдены: Паутиник фиолетовый (C.violaceus) и Ежовик коралловидный (H.coralloides).

Приуроченность макромицетов Кугарчинского района к определённым породам деревьев

Способность образовывать микоризу на своих корнях выражена, у различных деревьев неодинакова, с одними связаны десятки видов, с другими 
единицы. Некоторые виды грибов верны своим партнёрам и сопровождают деревья на всём протяжении их географического распространения, что и закреплено в название грибов (осиновик, березовик и т.д.) другие не так верны древесной породе [8].

Наибольшее число видов макромицетов 52 вида $(51,4 \%)$ встречается в хвойных лесах под сосной т.к. сосновые леса естественного происхождения располагаются вдали от населенных пунктов и преимущественно в горной местности. В этих лесах реже бывают люди и домашний скот, почвенный покров данных лесов пока еще мало нарушен. По литературным данным [9] данные леса в нашем районе являются сравнительно молодыми, поэтому редко подвергаются рубке. Значительное количество макромицетов обнаружено под берёзой - 43 вида (42\%). Достаточно большое количество макромицетов обнаружено также под следующими лиственными деревьями: под осиной - 26 видов $(25,5 \%)$, под липой - 26 видов $(25,5 \%)$, под тополем - 25 видов $(24,3 \%)$ и под дубом - 22 вида $(21,4 \%)$.

Нами выявлены 3 эвритопных вида макромицетов: Armillariella mellea (Tricholomataceae), Leccinum aurantiacum (Boletaceae), Laetiporus sulphreus (Sautigeraceae). Данные макромицеты являются неприхотливыми и имеют широкий диапазон в различных условиях обитания.

Большая часть макромицетов, в нашем случае 26 видов $(25,7 \%)$ являются облигатными.

Эколого-трофический анализ микобиоты Кугарчинского района

Субстрат является важным фактором в жизни шляпочных грибов, т. к. являясь гетеротрофными организмами, они получают из него все необходимые питательные вещества.

Микоризные грибы, живущие в симбиозе с высшими растениями, представлены только агариковыми макромицетами из таких порядков как Russulales, Boletales, Agaricales, из которых наибольшее количество микоризообразующих видов содержат Russula, Lactarius, Tricholoma, Suillus, 
Amanita и Leccinum. С сосной вступают в симбиоз Suillus granulatus, Boletus edulis и Lactarius deliciosus. Среди лиственных деревьев наибольшее количество микоризных грибов выявлено для березы. С березой вступают в симбиоз Boletus luridus, Leccinum scabrum, Lactarius torminosus, L. necator, L. resimus, Russula foetens и др. В посадках тополя встречается Tricholoma columbeta.

Наибольшее количество видов в группе ксилотрофов содержат порядки Agaricales и Aphyllophorales.

Виды гумусовых сапротрофов, растущие чаще вне леса, относятся к семействам Agaricales и Lycoperdales. Наиболее характерными являются Lactarius flexuosus, Marasmius oreades, Lycoperdon perlatum и др. Копротрофы поселяются на экскрементах или унавоженной почве. Большинство рудеральных видов относятся к семействам Coprinaceae u Strophariaceae. Они обильно заселяют припоселковые леса, а также приурочены к местам выпаса скота, лесным дорогам и человеческому жилью.

Среди сапротрофов можно выделить виды, которые для питания используют разные субстраты. На подстилке, почве, торфе, валеже и навозе встречаются Coprinus atramentarius, C. cyanescens, Agaricus arvensis и т.д.

Ресурсное значение макромицетов Кугарчинского района

Съедобные и ядовитые грибы не выделяются в какие-то особые таксоны, иногда и те и другие входят в состав одного и того же порядка, семейства и даже рода, являясь, таким образом, близкими родичами. Питательная ценность грибов зависит от различных факторов: метеорологических условий, почвенных, а также возраста грибов [10].

Преобладающей категорией по вкусовым и питательным качествам исследуемых макромицетов Кугарчинском районе являются съедобные грибы - 24 вида (54,1\%), наименьшей категорией обладают ядовитые грибы - 2 вида $(4,6 \%)$.

Грибы - это не только продукт питания, но и один из важных элементов биосферы, поддерживающих ее биологическое равновесие. Их уничтожение 
самым пагубным образом сказывается на процессах, связанных с биологическим циклом трансформации энергии. Поэтому, в связи с нарастающим антропогенными воздействиями на природу задача сохранения видового разнообразия становится все более актуальной. Выпадение отдельных групп организмов, происходящее под влиянием хозяйственной деятельности человека, обеднение видового разнообразия приводит к нарушению эффективного функционированию биогеоценоза и даже к полному его разрушению. Именно поэтому, для сохранения биоразнообразия живой природы, надо создавать охраняемые территории, заказники и питомники. На территории района нашего исследования такие территории отсутствуют, и нашей ведущей задачей является дальнейшее исследование и сохранение биоразнообразия живой природы для потомков. 


\section{Литература}

1. Горленко М.В., Бондарева М.А. Грибы СССР, Справочник-определитель географа и путешественника. - М.: Мысль, 1980. 303с.

2. Башкортостан: Краткая характеристика. Уфа: научное издательство «Башкирская энциклопедия», 1996. 672с.

3. Hansen L., Knudsen H. «Nordic Macromycetes», Vol. 2.: Polyporales, Boletales, Agaricales, Russulales. - Gopenhagen: Nordsvamp, 1992.

4. Hansen L., Knudsen H. «Nordic Macromycetes», Vol. 3.: Heterobasidioid, Aphyllophoroid and Gasteromycetoid basidiomycetes. - Gopenhagen: Nordsvamp, 1997.

5. Hansen. L., Knudsen H. «Nordic Macromycetes» Vol. 1. Ascomycetes. Copenhagen: "Nordsvamp", 2000.

6. Столярская М. В., Коваленко А. Е. Грибы Нижнесвирского заповедника. Вып. 1. Макромицеты (преимущественно агарикоидные базидиомицеты). СПб.: БИН РАН, 1996. 60 с.

7. Красная книга Республики Башкортостан : в 2 т. Т. 1 : Растения и грибы / под ред. д-ра. биол. наук, проф. Б. М. Миркина. - 2-е изд., доп. и переработ. - Уфа : МедиаПринт, 2011. - 384 с. : ил.

8. Смирняков Ю.И., Кощеев А.К., Спутник грибника. Карманный справочник. - М: Юнвес, ЧАО и К при участии ООО Ладья Бук, 2000. 448с.

9. Попов Г.В. Леса Башкирии. Уфа. Башкирское книжное издательство, 1980. $144 \mathrm{c}$

10. Дьяков Ю. Т. Грибы и их значение в жизни природы и человека. //Соровский обозревательный журнал, № 3, 1997. с. 38-45. 